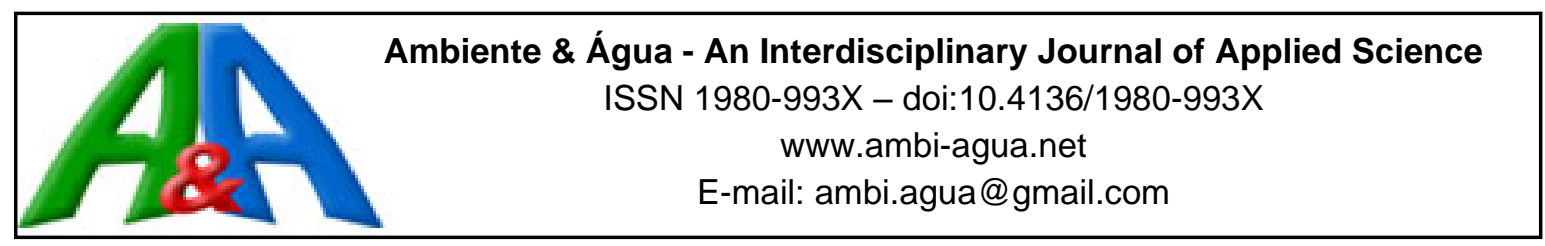

\title{
Payment for water-ecosystem services monitoring in Brazil
}

\author{
ARTICLES doi:10.4136/ambi-agua.2684
}

Received: 02 Dec. 2020; Accepted: 24 May 2021

\author{
Ana Paula Morais de Lima ${ }^{\text {* }}$; ; Rachel Bardy Prado ${ }^{2}$; Agnieszka Ewa Latawiec $^{3}$ [D \\ ${ }^{1}$ Departamento de Pesquisa e Desenvolvimento. Instituto Internacional para Sustentabilidade (IIS), Estrada Dona \\ Castorina, $\mathrm{n}^{\circ} 124$, CEP: 22460-320, Rio de Janeiro, RJ, Brazil. \\ ${ }^{2}$ Embrapa Solos (EMBRAPA), Rua Jardim Botânico, n 1024, CEP: 22460-000, Rio de Janeiro, RJ, Brazil. \\ E-mail: rachel.prado@embrapa.br \\ ${ }^{3}$ Centro de Ciências Sociais. Departamento de Geografia e Meio Ambiente. Pontifícia Universidade Católica do \\ Rio de Janeiro (PUC-RIO), Rua Marquês de São Vicente, n²25, CEP: 22541-041, Gávea, RJ, Brazil. \\ E-mail: a.latawiec@iis-rio.org \\ *Corresponding author. E-mail: a.lima@iis-rio.org
}

\begin{abstract}
The reduction of tropical forests has generated a loss of ecosystem services across the globe. In Brazil, essential biomes related to water provision (such as the Atlantic Forest and Savanna) have been degraded, compromising water-ecosystem services. Payment for waterecosystem services (water PES) has been implemented as a tool to stimulate changes in the use and management of these areas. Many water PES projects have emerged in Brazil using forest restoration, aiming to improve water ecosystem services. In this context, this study identified the types of monitoring carried out in Brazilian water PES projects, to include their main characteristics and gaps. Five Brazilian projects were selected for analysis as case studies. Interviews were then conducted with stakeholders to get current data on their monitoring practices. The data from the literature review, case study approach, and interviews were analyzed from the perspective of monitoring guides recommendations. Different aspects were analyzed, such as objectives, institutional arrangements, type of monitoring, indicators, and frequency of monitoring. The study indicates that there is a lack of standardized methods, making it difficult to specify the results of the implemented actions. The central gap is related to benefit monitoring. It is necessary to establish a holistic monitoring system, dealing with the ecosystem as a complex socio-ecological system. Some perspectives to solve the problems were proposed. The results of this work may help not only improve the current and future PES schemes in Brazil but also in other countries, especially developing ones, where vulnerable populations depend upon them.
\end{abstract}

Keywords: indicators, perspectives for water PES monitoring, water PES monitoring gaps.

\section{Monitoramento de pagamentos por serviços ambientais hídricos no Brasil}

\section{RESUMO}

A redução de florestas tropicais pelo mundo tem gerado uma significativa perca de serviços ambientais. No Brasil, biomas importantes relacionados a provisão de água (como a floresta Atlântica e Savana) têm sido degradados, comprometendo os serviços ambientais hidrológicos. Pagamentos por serviços ambientais relacionados a água (PSA hídrico) têm sido 
implementados como uma ferramenta para estimular mudanças no uso e manejo dessas áreas. Muitos projetos de PSA água têm surgido no Brasil fazendo uso da restauração para melhorar serviços ambientais relacionados a água. Nesse contexto, o objetivo desse estudo foi identificar os tipos de monitoramento realizados nos projetos de PSA hídrico brasileiros, suas principais características e lacunas. Cinco projetos brasileiros foram selecionados como estudo de caso para análise. Em seguida, foram realizadas entrevistas com stakeholders dos projetos selecionados visando obter dados atualizados das práticas de monitoramento. Os dados da revisão de literatura, abordagem de estudos de caso e entrevistas foram analisados sob a perspectiva das recomendações dos guias de monitoramento para PSA selecionados. Diferentes aspectos como, objetivos, arranjos institucionais, tipos de monitoramento, indicadores e frequência de monitoramento. $O$ estudo indicou que faltam métodos padronizados de monitoramento tornando difícil especificar os resultados das ações implementadas. A principal lacuna está relacionada ao monitoramento dos benefícios dos PSAs hídricos implementados. É preciso estabelecer um sistema de monitoramento holístico, abordando os ecossistemas como sistemas socio ecológicos complexos. Algumas perspectivas para resolver esses problemas foram propostas. Os resultados deste trabalho podem ajudar não apenas a melhorar os esquemas atuais e futuros de PSA no Brasil, mas também em outros países, especialmente países em desenvolvimento, dos quais populações vulneráveis dependem.

Palavras-chave: indicadores, lacunas do monitoramento de PSA- água, perspectivas para o monitoramento de PSA-água.

\section{INTRODUCTION}

Tropical forests provide a variety of ecosystem services such as water provision, climate regulation, and biodiversity conservation (Jenkins and Schaap, 2018; WWF, 2018). These benefits are often synergistic, meaning that protecting one ecosystem service (e.g. carbon) may also improve others, providing co-benefits (e.g. biodiversity) (Strassburg et al., 2012; Magnago et al., 2015). In some places, like Brazil, deforestation means not only losing or threatening these essential ecosystem services but also causing land degradation and increased erosivesedimentary processes, reducing soil quality and compromising the quality and quantity of water (ANA, 2012; 2013).

Despite its importance, the area of tropical forests has been reducing throughout the world due to extensive practices of agriculture, burning, illegal logging, and unsustainable management (Strassburg et al., 2014; Latawiec et al., 2015). Gibbs et al. (2010) show that the demand for agricultural products and pasture has increased the demand for land. In Brazil, a significant proportion of forest cover has been drastically reduced, mainly due to the expansion of the agricultural and livestock frontier. According to FAO (2016), more than 80 per cent of the deforestation that occurred in Brazil between 1990 and 2005 was associated with conversion to pastures. It is estimated that between 15 and 18 percent of the Amazon biome has been deforested (Brasil, 2012). In contrast, other globally and locally important biomes, such as the Savanna, Pampas, and Caatinga lost approximately 50 per cent of their natural cover, and in the Atlantic Forest, around ninety per cent (Brasil, 2012).

Deforestation and changes in land cover can promote alterations in the water cycle compromising the quality and quantity of water available for human consumption. It is estimated that one billion people globally have limited access to water to support their daily needs (UNESCO, 2015a). United Nations alert for an impending global water crisis. If there is no significant change in the use and management of water resources, the world will suffer a 40 per cent shortage in water supply by 2030 (UNESCO, 2015b). While the world population and water consumption have increased over the last century, erosion processes have intensified 
decreasing water quality for consumption (Richards and Jenkins, 2007). Brazil is one of the world's largest water holders, with thirteen percent of the planet's freshwater. This is almost two times more than Russia and about four times more water than Canada, Indonesia, China, Colombia, and the United States (ANA, 2013). Despite this apparent abundance, Brazil experienced a severe water crisis in 2014 and 2015 with water shortages and rationing in vast areas of the country (ANA, 2015). This episode demonstrated flaws in water management in Brazil, and highlighted an urgent need to understand better water regulation in the country as well as better monitoring of Brazil's water resources.

Despite the richness of all of Brazil's biomes, it is estimated that 53 per cent of the remnants of native vegetation occur on private rural properties, hindering the restoration process (Soares-Filho et al., 2014). In that context, payment for water ecosystem services has emerged as a potential tool to stimulate landowners to adopt conservation practices. Payments for Ecosystem Services (PES) are a globally recognized and applied incentive scheme to stimulate transactions regarding certain ecosystem services and financially compensate the providers of these services (Blundo-Canto et al., 2018). Up to mid-2009, there were about 150 PES programs and projects in Latin America (Pagiola et al., 2012; Bremer et al., 2016), operating approximately 2.5 million hectares (Camhi and Pagiola, 2009).

Through the complexity of global environmental problems, it is increasingly necessary to think about joint actions that integrate culture and nature. Global biomes are already intensely transformed (Ellis and Ramankutty, 2008). Despite its potential shortcomings (Locatelli et al., 2013), PES is a fascinating mechanism, since it allows the coexistence of production systems together with conservation actions, besides providing a financial incentive to those involved (Prado et al., 2017).

Payments for water ecosystem services have been developed in the context of water scarcity and increased demand for this resource (Nusdeo, 2013; Goetz, 2019). In Brazil, the most well-known water PES is the Water Producer Program (WPP) of the National Water Agency (ANA). WPP is a national government program to stimulate the implementation of water PES projects in strategic basins for restoration and water supply (ANA 2013). There are also water PES projects implemented and financed by the private sector. The main focus of these programs is the provision of hydrological ecosystem services, defined as the benefits offered by terrestrial ecosystems, which include freshwater supply, water quality regulation, flood mitigation, erosion control, and water-related cultural services (Brauman et al., 2007; Terrado et al., 2009).

The increasing number of these projects in Brazil in the last years demand attention to the effectiveness of these actions in the provision of water ecosystem services. PES effectiveness is a key element for a successful program (Goetz, 2019). This effectiveness can be identified in the project's monitoring and evaluation results. Monitoring and evaluation are essential components of the successful management of any intervention (UNEP-WCMC and FEBA, 2020). Monitoring is the process of collecting data and information about something over time to detect signs of change concerning baseline (Higgins and Zimmerling, 2013; UNEP-WCMC and FEBA, 2020). "Evaluation is the process of examining the monitoring data collected to understand what difference an intervention has made and what lessons can be learned" (UNEPWCMC and FEBA, 2020). Due to the growth of PES water initiatives in Brazil, it is necessary to turn attention to how monitoring has been carried out identifying the results of these initiatives, gaps, positive and negative impacts and the improvements that need to be done.

This study aims to contribute to the advancement of knowledge on this topic, presenting an overview of Brazil water PES monitoring, identifying gaps and perspectives. The purpose is to analyze on-going Brazilian monitoring systems established by the programs themselves to track change over time. Five water PES initiatives were selected as case studies for analysis. 


\section{MATERIALS AND METHODS}

The methodological approach applied in this study consisted of four consecutive steps (Figure 1): 1) literature review about Brazilian PES water monitoring systems; 2) selection and analysis of PES water case studies; 3) interview with case studies stakeholders; and 4) analysis and interpretation of all data collected. Data about the objectives, institutional arrangement, monitoring methods, and indicators were collected (from the literature review and interviews) for each case study.

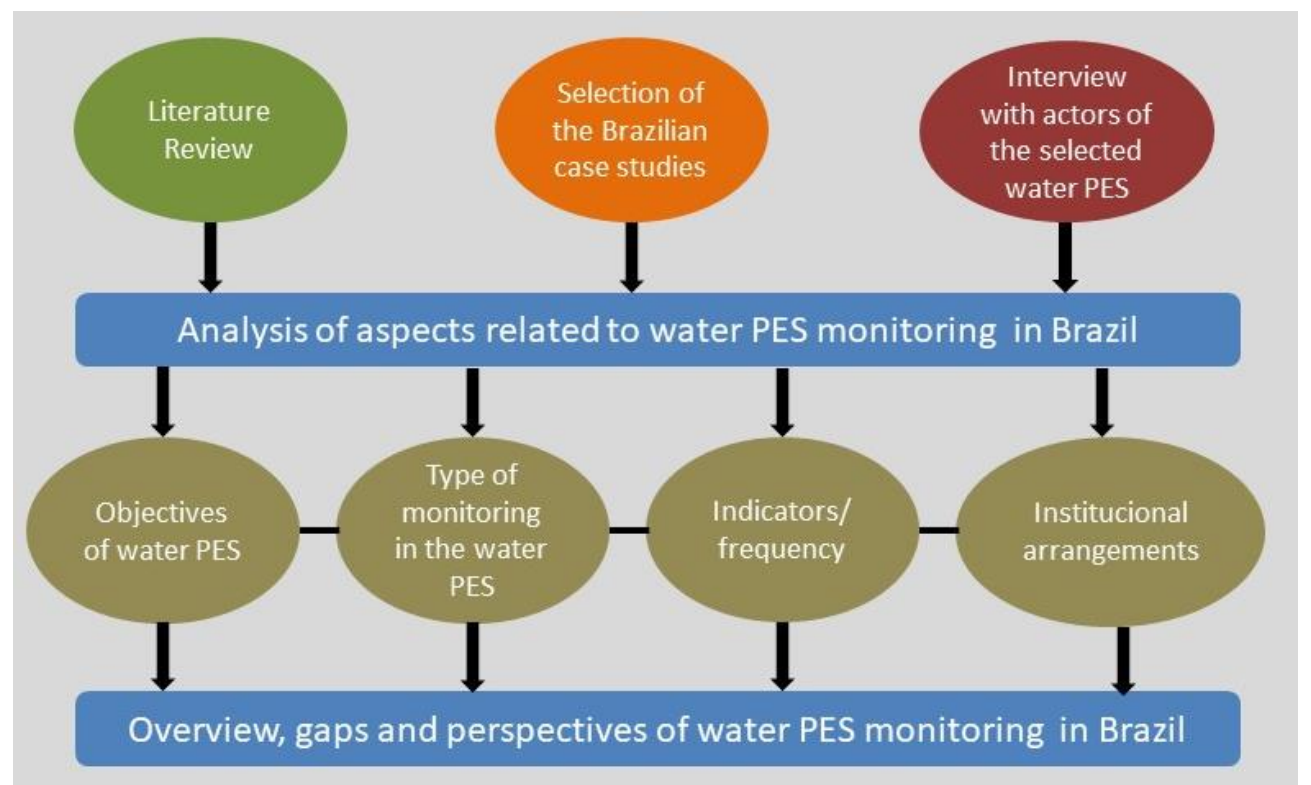

Figure 1. Methodological procedures.

\subsection{Literature Review}

The first step was a bibliographic review of water PES monitoring in Brazil. This survey was carried out using national and international bibliographic databases. The national bibliographic databases were: Alice, Infoteca, Sabiia (all are bibliographic bases of Brazilian Agricultural Research Corporation-Embrapa). The international bibliographic databases were: Science Direct and Scopus. The keywords used in the survey were: Payment for ecosystem services (PES), Water, Monitoring, and Brazil. This step provided subsidies to identify existing PES water projects in Brazil and to identify which projects had more information available for analysis.

Aiming to obtain specific information about on-going monitoring systems established by the PES water programs themselves, the bibliography available on the website of the Water Producer Program and the Oasis program website was also consulted. From this search, the following information on water PES projects was collected: project name, project location, institutions responsible for monitoring, project objectives, frequency of monitoring, monitored indicators and parameters, types of monitoring performed, bottlenecks, recommendations of each project implemented. Few projects identified in literature review and website searches presented information about all these fields. Therefore, having available monitoring information was one of the criteria for selected case studies for a more in-depth analysis.

\subsection{Case Studies}

In this study, we opted to use the case study approach to make the analyses more focused and concrete. The case studies are projects from two water PES programs that can be highlighted in Brazil: the Water Producer Program (WPP) of the National Water Agency 
(ANA), which is a public initiative, and the Oásis Program (OP) of the Boticario Protection of Nature Foundation, which is a private initiative. The Water Producer Program aims to provide support for the implementation of water PES in regions with high water demand and degradation. The main objective of the WPP is to increase the quantity and quality of the water and to reduce the erosive-sedimentary process in the contemplated basins (ANA, 2013).

The OP aims to increase the quality and quantity of available water and restore the forest stretches producing systemic benefits. In this work, we consider as a 'Program', initiatives of the same institution that have a significant proportion and develop several projects following the objectives and methodologies proposed by the Pilot Program. 'Projects' are local initiatives, resulting from a program. The term "PSA initiatives" encompasses projects and programs

The water PES projects (case studies) were selected from 3 criteria: location in the most critical biomes in terms of public water supply (largest population and water scarcity), being older and more advanced in the country, and having a large amount of information and data related to monitoring. The projects selected were (Figure 2): Oásis Brumadinho (OP), Water Conservator (WPP), Water Producer Camboriú (WPP), Water Producer Pipiripau (WPP), and Water Producer Guandu (WPP). These projects are on the Atlantic Forest and Savanna (Figure 2), the highly Brazilian degraded biomes, and global biodiversity hotspots (Laurance, 2009). Although fragmented, these biomes provide essential ecosystem services such as water supply and regulation for the majority of the Brazilian population.

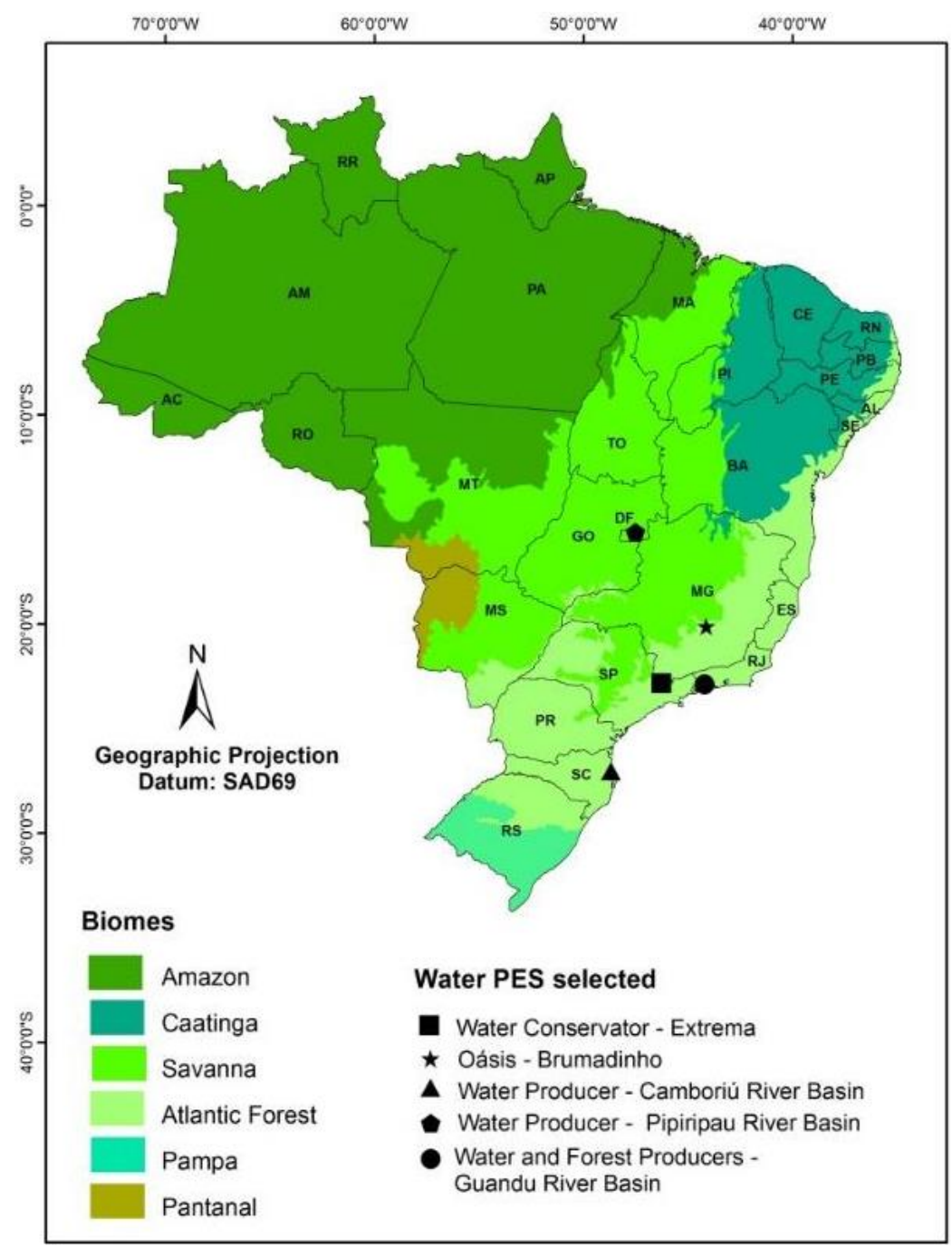

Figure 2. Brazilian biomes map and the location of water PES case studies. 
The Atlantic Forest covers about 15 percent of the Brazilian territory, and that space is home to 72 percent of the Brazilian population (SOS Mata Atlântica, 2020) Three of the largest urban centres in South America are in that territory (SOS Mata Altântica, 2020). This biome is the most populated in Brazil. It has therefore been significantly degraded, compromising water services. The lack of water in quantity and quality is already a problem in 53 per cent of Brazilian municipalities, which have problems with silting up water bodies, resulting from the suppression of vegetation along rivers (APPs), and 38 percent of them suffer from water pollution (SOS Mata Atlântica, 2020). Four of the study cases (Water conservator, Oásis Brumadinho, Water producer Camboriú and Water and Forest producers) are situated in the context of Atlantic Forest degradation, increasing demand for water services, and inducing water scarcity.

The water producer Pipiripau is situated in Brazil capital, on the Savanna biome. This biome is also vital for water resources. It is known as the "cradle of waters," because it houses several springs that supply critical watersheds that take water to other biomes such as the Amazon and Atlantic Forest (IBGE, 2018). However, despite all this value, 49 per cent of the biome was deforested to be converted into pastures, crops, hydroelectric dams, mines, and urban areas, and just 8 percent of native vegetation is protected (IBGE, 2018). However, the low precipitation rates in the last years have impacted the storage of the main supply reservoirs on the Savanna (ANA, 2018).

\subsection{Stakeholder interviews}

Considering the gaps of PES data monitoring in the literature, individual structured interviews were conducted to gather detail about the case study monitoring process. Due to the geographic distance between the locations of the case studies, contact was made by e-mail. An email explaining the research was sent to each PES-project contact. The email requested a recommendation for the best person to answer questions related to project monitoring. The choice of the technical expert team to be interviewed was thereby made according to involvement in the related monitoring. The questionnaire used in the interview is included below (Table 1). The interviews were conducted in 2016 and updated in 2020, following the same procedures. The most updated data were considered for analysis.

The structured interview consists of a series of questions designed to elicit a specific response or answer from respondents The questions are generally specific, and the context of the questions is the same for all participants involved in the research (Formplus,2020).

Table 1. The questionnaire applied to the case-study stakeholders.

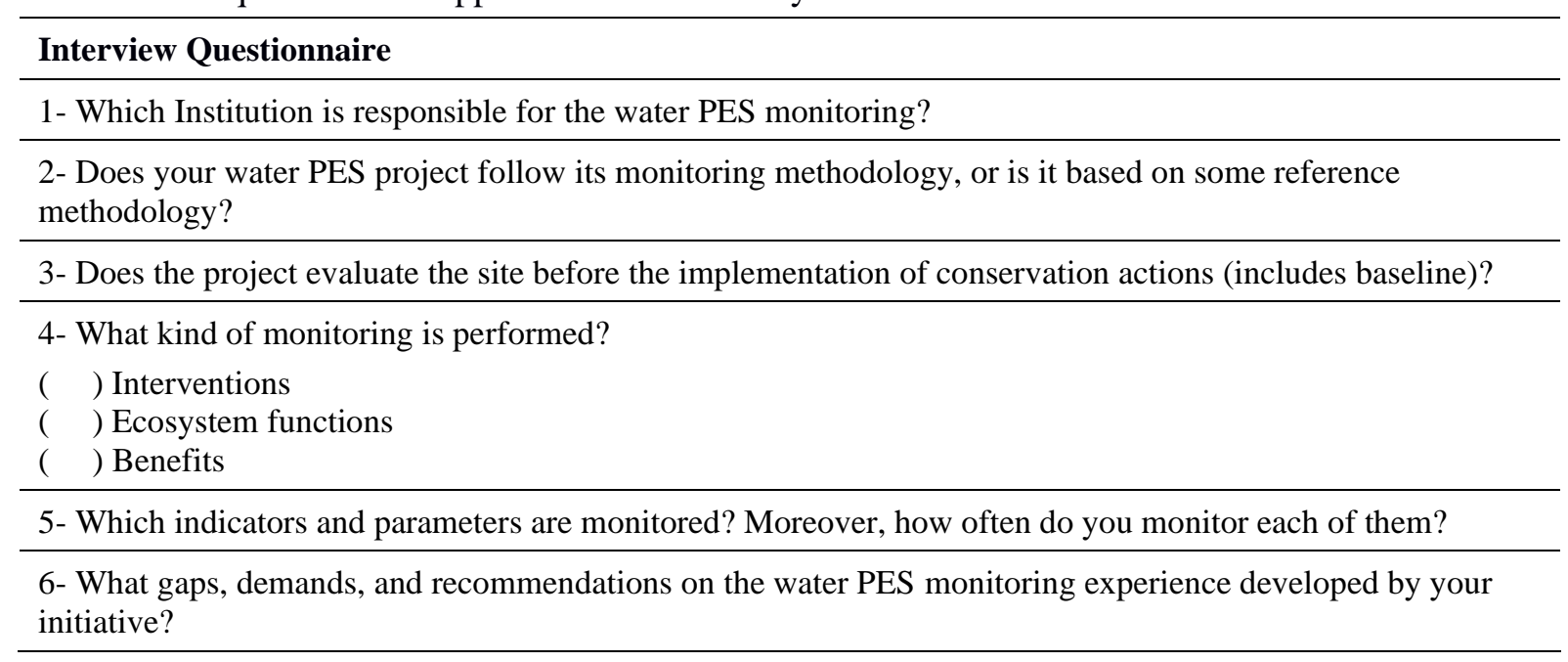

Rev. Ambient. Água vol. 16 n. 4, e2684 - Taubaté 2021 


\subsection{Overview, gaps, and perspectives analysis related to water PES monitoring}

Regarding classification of the monitoring type and identifying its indicators and frequency, data were organized based on the conceptual model developed by Turetta et al. (2013), adapted from Haines-Young and Potschin (2010), Martins et al. (2013). This included functions, structure (interventions) and benefits (socioeconomic). This model consists of a conceptual cascade analysis model. The structure refers to the project's implemented actions. All interventions aim to influence ecosystem functions to promote benefits for society. In this way, we considered monitoring of the interventions as the monitoring of the actions established in the contract with the producer so that he/she receives payment for the ecosystem services supposedly provided. Some examples of indicators of intervention are the fences, the repair of roads, and the number and condition of the seedlings planted. Ecosystem function monitoring is understood as the monitoring of responses of the ecosystem to the conservation actions implemented by the water PES. In this monitoring, periodic surveys of the physical, chemical, and biological conditions of the environment are carried out, and indicators such as flow, water turbidity, presence of fish and birds, soil compaction, and others may be cited. Benefit monitoring is related to the impacts of the project on the social and economic conditions of the community involved. Some examples are per capita income, jobs created, improvement of water supply, local articulation, and well-being.

The information of each case study was organized into tables that combine the data collected in the literature review and the interviews. The leading information organized in tables used to analyze the overview was: PES objectives, type of monitoring, indicators for each type for monitoring, frequency of indicator monitoring, institutional arrangements, gaps, and perspectives of the water PES monitoring. This information was critically analyzed based on monitoring guide recommendations: a) "A primer for monitoring water funds" (Higgins and Zimmerling, 2013); b) "Guidebook for monitoring and evaluating ecosystem-based adaptation interventions" (UNEP-WCMC and FEBA, 2020); c) "Manual para pagamentos por serviços ambientais hídricos" (Fidalgo et al., 2017); and discussion comparing the case study with other PES water experiences worldwide reported in the literature. Based on that analysis and the literature review and interview information, the main gaps for monitoring water PES and perspectives to solve them were listed.

\section{RESULTS AND DISCUSSION}

\subsection{Water PES objectives}

The main objectives of Brazilian water PES projects are to improve the quality and quantity of water (Table 2), primarily through the reduction of the sedimentation process, which is a significant problem in the Brazilian rural environment. When the erosion rate is higher than the rate of soil formation (pedogenesis), there are significant economic impacts. There is (on average) a tolerance of between 9 and 12 tons per hectare per year. In Brazil, the average erosion rates were 25 tons per hectare per year in 2009 (ANA, 2009). Recent research shows that Brazil still presents high rates of erosion (Pereira et al., 2019). These high rates of erosion cause the loss of soil nutrients and decrease water quality and quantity due to intense sedimentation.

Table 2 shows the objectives, type of monitoring, and monitoring-related institutions of each case study. One hundred percent of the case studies include monitoring of interventions, environmental aspects, and benefits. As we can see in Table 2, the case studies' objectives focus on environmental issues, and this reflects directly in the monitoring indicators. Besides that, the objectives are general. Specific goals are rare. 
Table 2. Objectives, type of monitoring, and related institutions of case studies.

\begin{tabular}{|c|c|c|c|}
\hline Projects & Objectives & Type of monitoring & Related institutions* \\
\hline Water Conservator & $\begin{array}{l}\text { Effectively reduce erosion and } \\
\text { sedimentation processes, } \\
\text { Increase land cover, } \\
\text { Improve the quality and quantity of the } \\
\text { water resources, } \\
\text { Ensure the socioeconomic and } \\
\text { environmental sustainability of } \\
\text { conservation practices }\end{array}$ & $\begin{array}{l}\text { Ecosystem function, } \\
\text { interventions, and } \\
\text { benefits }\end{array}$ & $\begin{array}{l}\text { UFLA, USP SP e USP } \\
\text { Esalq, Unicamp, Embrapa } \\
\text { Jaguariuna }\end{array}$ \\
\hline Oásis Brumadinho & $\begin{array}{l}\text { Preserve natural areas and springs, } \\
\text { Stimulate sustainable practices of land } \\
\text { use, } \\
\text { Promote and increase in the area and } \\
\text { quality of the land cover through } \\
\text { ecological restoration, } \\
\text { Contribute to improving the quality of } \\
\text { life of the population involved in the } \\
\text { PES }\end{array}$ & $\begin{array}{l}\text { Ecosystem function, } \\
\text { interventions, and } \\
\text { benefits }\end{array}$ & $\begin{array}{l}\text { Mineira association for } \\
\text { environmental protection } \\
\text { (AMDA) and O Boticario } \\
\text { Foundation of Nature } \\
\text { Protection }\end{array}$ \\
\hline $\begin{array}{l}\text { Water producer } \\
\text { Camboriú }\end{array}$ & $\begin{array}{l}\text { Preserve and restore riparian zones and } \\
\text { areas with the potential to promote the } \\
\text { regulation of water flows, } \\
\text { Increase the quantity and quality of the } \\
\text { water resources, } \\
\text { Not compromise the socioeconomic } \\
\text { context in which the community is } \\
\text { inserted }\end{array}$ & $\begin{array}{l}\text { Ecosystem function, } \\
\text { interventions, and } \\
\text { benefits }\end{array}$ & $\begin{array}{c}\text { EMASA, Balneário } \\
\text { Camboriú City Hall, } \\
\text { EPAGRI (Agricultural } \\
\text { Research and Rural } \\
\text { Extension Company of } \\
\text { Santa Catarina), TNC (The } \\
\text { Nature Conservancy), ANA } \\
\text { (Nacional Water Agency). }\end{array}$ \\
\hline $\begin{array}{l}\text { Water producer } \\
\text { Pipiripau }\end{array}$ & $\begin{array}{l}\text { Ensure water quantity and quality, } \\
\text { Reduce erosion, } \\
\text { Contribute to the regulation of the } \\
\text { hydrological regime of rivers, }\end{array}$ & $\begin{array}{l}\text { Ecosystem function, } \\
\text { interventions, and } \\
\text { benefits }\end{array}$ & $\begin{array}{l}\text { UnB, WWF, IBRAM, } \\
\text { Emater-DF }\end{array}$ \\
\hline $\begin{array}{l}\text { Water and forest } \\
\text { producers Guandu }\end{array}$ & $\begin{array}{l}\text { Improve the number of water resources } \\
\text { in the Guandu Basin, } \\
\text { Improve water-quality indicators, } \\
\text { Reduce sedimentation, } \\
\text { Increase land cover, } \\
\text { Generate employment and income }\end{array}$ & $\begin{array}{l}\text { Ecosystem function, } \\
\text { interventions, and } \\
\text { benefits }\end{array}$ & $\begin{array}{l}\text { TNC (The nature } \\
\text { conservancy) and Guandu } \\
\text { Watershed Committee. }\end{array}$ \\
\hline
\end{tabular}

Source: Lima (2016) and Bremer et al. (2016) and interviews.

\subsection{Influence of institutional arrangements on water PES monitoring in Brazil}

A striking characteristic of Brazilian water PES is the diverse institutional configuration of each project (Table 2). Several institutions involved in monitoring have led to the dispersion of data on the monitoring of water PES (Lima, 2016). Therefore, it is necessary to create integrated channels of systematization and dissemination of the results of the water PES monitoring, allowing a systemic analysis of all results by the society and actors that pay for PES (Lima, 2016; Prado et al., 2017).

On the other hand, this diversity of institutions involved in the monitoring of water PES projects has been the way to maintain their continuity, given the technical and financial limitations. There are many difficulties related to the costs of monitoring, installation, and maintenance of equipment and specialized technical staff (Pagiola et al., 2012; Novaes, 2014; Lima, 2016; Prado et al., 2017). Therefore, developing partnerships becomes an interesting mechanism for the sustainability of monitoring of the project's impacts, but needs to be improved to overcome the bottlenecks of information dispersion, and unavailability of the integrated data for society identified in this research.

The organization and availability of monitoring data are essential for the process of evaluating short- and long-term results. Besides that, all the stakeholders involved (such as 
donors, investors, participating communities, and managing partners) are interested in knowing how the project is evolving. Monitoring and evaluation can provide the answer (Higgins and Zimmerling, 2013). Institutional diversity could help with this point by monitoring the evolution of the PSA for each stakeholder.

\subsection{Water PES monitoring - Indicators in Brazil: case studies}

Indicators are units of information (related to objects, conditions, characteristics, and behaviour) that represent the broader environmental, socioeconomic, or climatic situation. They can be quantitative or qualitative (UNEP-WCMC and FEBA, 2020). Selection of the most appropriate indicators to monitor is essential because they will indicate if the objectives are being achieved. Therefore, the indicators need to be aligned with the project objectives (Turetta et al., 2013; Lima, 2016). However, the selection of indicators to monitor water PES is a challenge. The indicators recommended by the scientific community as ideal for monitoring are often not viable in practice due to costs or their complexity (Latawiec and Agol, 2015). It is crucial to establish indicators which the community involved identifies itself in some way. There are many ways to organize and classify indicators. In Table 3, they are organized considering the classes: function, structure, and benefits. Table 3 summarizes the data collected in the literature and interviews related to indicators and Its frequency of Brazilian PES water case studies.

Of the Brazilian water PES projects analyzed, 49 monitoring indicators were identified. Approximately, 70 percent of these indicators are related to ecosystem functions (they seek to evaluate the physical-chemical conditions of the environment). Twenty-four percent of the indicators evaluate the structure or interventions carried out in the project area. Only 6 percent of the indicators are related benefits, seeking to assess the impacts of the PES water on the community involved. Benefit indicators can be an essential key to understanding the outcomes related to providing services and human well-being. Considering society and nature as separate elements is inadequate, given the predominance of complex socio-ecological systems throughout the world (Ellis and Ramankutty, 2008). It is critical to consider that ecological and social systems are highly connected and coevolving in space-time. Besides that, the ecosystem approach emphasizes that the decisions about ecosystem services should be considered in social and economic contexts (Haines Young and Potschin, 2010).

The literature presents that socioeconomic and benefit monitoring in Brazilian PES projects is scarce, and in the case of some projects, even non-existent (Pagiola et al., 2012; Novaes, 2014; Lima, 2016). Based on the interviews, we identified that there was progress in the implementation of socioeconomic monitoring. There has been a concern with the socioeconomic issue by the owners involved, and, thus, the search for indicators that indicate the state of these stakeholders involved in the project. However, the weight of environmental indicators is still much more immense. Socioeconomic indicators have been identified as a necessity, and this has been implemented in initial experiences. Greiner and Stanley (2013) point out that PES is associated with poverty reduction, income generation, and social benefits. On the other hand, the authors point out that very poor landowners cannot participate in PES programs because of the high transaction costs associated with participation in these schemes.

By comparing the indicators and the frequency of water PES monitoring projects, a variation of the monitoring standards is observed, which makes it difficult to relate the results of the projects. Frequency standardization has occurred in PES projects for indicators monitored by automated equipment. The absence of methodological standards still characterizes Brazilian PES. It is necessary to create more reliable scientific methods that can be used as a reference basis for the various PES implemented around the world and that face the same complexity in the monitoring process (Meijerink, 2008). It is necessary to carry out a more integrated analysis of indicators, aiming to generate more robust responses (Latawiec and Agol, 2015). 
Table 3. Indicators and frequency of water PES monitoring in the Brazilian projects studied.

\begin{tabular}{|c|c|c|c|c|c|c|}
\hline \multirow{2}{*}{$\begin{array}{c}\text { Type of } \\
\text { monitoring }\end{array}$} & \multirow[t]{2}{*}{ Indicators } & $\begin{array}{c}\text { Water } \\
\text { Conservator* }\end{array}$ & $\begin{array}{c}\text { Oásis } \\
\text { Brumadinho }\end{array}$ & $\begin{array}{l}\text { Water Producer } \\
\text { Camboriú }\end{array}$ & $\begin{array}{c}\text { Water Producer } \\
\text { Pipiripau }\end{array}$ & $\begin{array}{l}\text { Water and Forest } \\
\text { Producers Guandu }\end{array}$ \\
\hline & & \multicolumn{5}{|c|}{ Frequency of monitoring } \\
\hline \multirow{26}{*}{$\begin{array}{l}\text { Ecosystem } \\
\text { functions }\end{array}$} & Precipitation & $\mathrm{m}$ & $\mathrm{NP}$ & $\mathrm{H}$ & $\mathrm{m}$ & M \\
\hline & Distribution of precipitation & NP & NP & NP & NP & M \\
\hline & Accumulated distribution & $\mathrm{NP}$ & $\mathrm{NP}$ & NP & NP & M \\
\hline & Number of rainy days & NP & NP & NP & NP & M \\
\hline & Number of days without rains & NP & NP & NP & NP & M \\
\hline & Number of days with rainy events & $\mathrm{NP}$ & NP & NP & NP & M \\
\hline & Air temperature & $\mathrm{m}$ & NP & $\mathrm{H}$ & NP & NP \\
\hline & Atmospheric pressure & $\mathrm{NP}$ & NP & $\mathrm{H}$ & NP & NP \\
\hline & Wind speed & NP & NP & $\mathrm{H}$ & NP & NP \\
\hline & Air moisture & $\mathrm{NP}$ & NP & NP & NP & $\mathrm{NP}$ \\
\hline & Solar radiation & NP & $\mathrm{NP}$ & $\mathrm{H}$ & NP & $\mathrm{NP}$ \\
\hline & Leaf wetting & $\mathrm{NP}$ & $\mathrm{NP}$ & $\mathrm{H}$ & NP & $\mathrm{NP}$ \\
\hline & Water flow & $\mathrm{m}$ & SA & $\mathrm{m}$ & Q & M \\
\hline & Water level & $\mathrm{m}$ & SA & $\mathrm{H}$ & Q & $\mathrm{m}$ \\
\hline & Water turbidity & $\mathrm{m}$ & SA & $\mathrm{H}$ & $\mathrm{Q}$ & $\mathrm{m}$ \\
\hline & Water temperature & $\mathrm{B}$ & SA & $\mathrm{H}$ & NP & $\mathrm{NP}$ \\
\hline & Water total suspended solids & NP & NP & $\mathrm{H}$ & NP & $\mathrm{M}$ \\
\hline & Water dissolved oxygen & $\mathrm{B}$ & SA & $\mathrm{H}$ & NP & NP \\
\hline & Water $\mathrm{pH}$ & $\mathrm{B}$ & SA & $\mathrm{H}$ & NP & $\mathrm{R}$ \\
\hline & Water electrical conductivity & $\mathrm{B}$ & SA & $\mathrm{H}$ & NP & $\mathrm{R}$ \\
\hline & Water organic matter & $\mathrm{NP}$ & NP & $\mathrm{H}$ & NP & $\mathrm{NP}$ \\
\hline & Water total phosphorus & NP & NP & $\mathrm{H}$ & NP & NP \\
\hline & Water nutrients & $\mathrm{NP}$ & NP & $\mathrm{H}$ & NP & $\mathrm{NP}$ \\
\hline & Water sediments & NP & NP & NP & NP & M \\
\hline & Water infiltration & NP & NP & NP & NP & NP \\
\hline & Electric conductivity & NP & SA & NP & $\mathrm{NP}$ & $\mathrm{R}$ \\
\hline ontinue... & & & & & & \\
\hline
\end{tabular}




\begin{tabular}{|c|c|c|c|c|c|c|}
\hline Continued... & & & & & & \\
\hline \multirow{8}{*}{$\begin{array}{l}\text { Ecosystem } \\
\text { functions }\end{array}$} & Runoff & NP & NP & NP & NP & M \\
\hline & Land use/cover & NP & NP & NP & NP & $\mathrm{BA}$ \\
\hline & Groundwater level & NP & NP & NP & NP & NP \\
\hline & Avifauna & NP & NP & BA & NP & $\mathrm{BA}$ \\
\hline & Ictiofauna & NP & NP & BA & NP & $\mathrm{BA}$ \\
\hline & Mastofauna & NP & NP & BA & NP & NP \\
\hline & Herpetofauna & NP & NP & BA & NP & NP \\
\hline & Carcinofauna & NP & NP & BA & NP & NP \\
\hline \multirow{12}{*}{ Struture } & Soil conservation & NP & SA & NP & $\mathrm{Q}$ & NP \\
\hline & $\begin{array}{c}\text { Permanent Preservation areas and legal } \\
\text { reserves }\end{array}$ & NP & SA & NP & NP & $\mathrm{NP}$ \\
\hline & Presence of endangered species & NP & SA & NP & NP & NP \\
\hline & Presence of invasive species & NP & SA & NP & NP & NP \\
\hline & Vegetation stage & NP & SA & NP & NP & NP \\
\hline & Erosion control practices & NP & SA & NP & A & NP \\
\hline & Use of native wood & NP & SA & NP & NP & NP \\
\hline & Sanitation condition & NP & SA & NP & NP & NP \\
\hline & Number of endangered species & NP & SA & NP & NP & NP \\
\hline & Use of native wood & NP & SA & NP & NP & NP \\
\hline & Class of agrochemical used & NP & SA & NP & NP & NP \\
\hline & Adoption of organic production & NP & SA & NP & NP & NP \\
\hline \multirow{3}{*}{ Benefits } & Jobs created with water PES & NP & NP & NP & NP & NP \\
\hline & $\begin{array}{l}\text { Perception of rural producers and agents } \\
\text { involved in project management }\end{array}$ & NP & NP & BA & NP & NP \\
\hline & $\begin{array}{l}\text { Motivation of producers related to water } \\
\text { PES }\end{array}$ & NP & NP & SA & NP & NP \\
\hline
\end{tabular}

Legend: Every 15 min (m), Hourly (H), Random (R), Monthy (M), Bimonthly (B), Quartely (Q), Annually (A), Biannualy (BA), Semi Annually (SA), Does not perform (NP).

Source: Lima (2016), Bremer et al. (2016) and interviews (2016 and 2020). 


\subsection{Gaps and perspectives related to water PES monitoring}

Martin-Ortega et al. (2013) identified that there are large gaps in the way PES monitoring experiences are reported in the literature, with no monitoring of ecosystem services and human welfare and a significant focus on interventions. Previous studies (Pagiola et al., 2012, Novaes, 2014; Lima et al., 2016) indicated that Brazilian water PES monitoring is carried out on a caseby-case basis, with no standardization of methods, indicators, and frequency. The case study analyses highlighted the lack of patterns in monitoring methods, as four projects of the same program (Water Producer) have different methods, indicators, and frequency of monitoring. In the interviews conducted with the professionals involved in water PES monitoring of the selected projects, it was observed that standardization of the methods is incipient. Some factors that can contribute to this standardization are the use of automatic equipment (which generates data at the same frequency) and the use of monitoring guides like "A primer for monitoring water funds" proposed by The Nature Conservancy (Higgins and Zimmerling, 2013) and Fidalgo et al. (2017) among others.

The monitoring of PES projects is essential to identify their effectiveness and their environmental and socioeconomic consequences. However, the lack of adequate monitoring has been identified as a significant bottleneck of these schemes (Pagiola et al., 2012; Lima et $a l ., 2016)$ with socioeconomic monitoring likely being the largest gap (Novaes, 2014; Lima, 2016). Lack of clear monitoring objectives, the difficulty of monitoring of the impacts of conservation actions on ecosystem services (Lima, 2016), high cost of monitoring (Veiga e Gavaldão, 2011), lack of continuous funding, and lack of baseline monitoring (Novaes, 2014; Lima, 2016) are just a few examples reported in the literature. For these reasons, it is expected that the monitoring is related to landowner practices, rather than to environmental and socioeconomic impacts (Novaes, 2014; Lima, 2016; Prado et al., 2017), hindering the assessment of whether the PES scheme was successful for ecosystem service provision in the long term. In the case of Brazil, monitoring of PES lacks coherent methodological guidelines to be followed. A large methodological variety used in monitoring makes it difficult to analyze and compare results between projects (Veiga and Gavaldão, 2011; Lima, 2016).

The interviewees mentioned some gaps in the water PES, such as high cost of monitoring, demand for specialized technical staff to carry out long-term monitoring, and difficulty in proving the impacts of conservation actions on ecosystem services and benefits to communities involved with water PES. Although there is a kind of monitoring in each of the projects, not all have a monitoring evaluation system. Data is collected and transformed into reports, but not evaluated. Table 4 summarizes the perception of literature, interviewees, and authors of this paper regarding gaps related to water PES monitoring and some perspectives to solve them.

On water PES, it is common to connect forest conservation and restoration to water provision. Martin-Ortega et al. (2013) point out that forest management is the heart of the PES, being the predominant objective in all evaluated programs. Brouwer et al. (2011) also evaluated several PES schemes around the world and identified that 70 per cent of the indicator of high relevance was forest cover. However, recent research has pointed out that increasing forest cover may reduce the amount of water available in the short term (Filoso et al., 2017). It has to be considered on the timeline of expected results and in the monitoring process. The perception of increasing water availability will be realized with long-term monitoring.

In general, the exchange of experiences between PES can avoid the repetition of several bottlenecks. Reducing costs, using more affordable and cheaper methods also facilitates monitoring. Another critical issue is the communication between the different institutions that operate the projects. The information needs to be integrated, not dispersed, and be accessible to society. Baseline monitoring is indispensable for assessing conditions before project implementation. The interviews also corroborated the results from the literature review about the importance of performing benefit monitoring in PES initiatives. 
Table 4. Perception regarding gaps related to water PES monitoring and some perspectives.

\begin{tabular}{lll}
\hline Aspects & Status/Gaps & Perspectives \\
\hline Objectives & $\begin{array}{l}\text { The Brazilian water PES presents } \\
\text { general objectives. "Without clear } \\
\text { goals and objectives, Water Funds } \\
\text { cannot determine what they are } \\
\text { trying to achieve or whether they } \\
\text { have been successful in achieving } \\
\text { it (Higgins and Zimmerling, 2013, } \\
\text { p.6). }\end{array}$ & $\begin{array}{l}\text { The project's objectives should be directly linked to } \\
\text { the most relevant information. The objectives give } \\
\text { support for the questions that the monitoring process } \\
\text { has to answer with data collection and analysis } \\
\text { (Higgins and Zimmerling, 2013; UNEP-WCMC and }\end{array}$ \\
& $\begin{array}{l}\text { FEBA, 2020). Developing specific short and long- } \\
\text { term goals with experts and stakeholders in the } \\
\text { planning stage can direct the project monitoring }\end{array}$ \\
& $\begin{array}{l}\text { actions on the timeline. Following the SMART } \\
\text { framework, the objectives have to be: specific, } \\
\text { measurable, achievable, realistic, and Time-bound. }\end{array}$ \\
& $\begin{array}{l}\text { This type of criteria is a guide to establish and } \\
\text { organize project goals. Example of goal based on the }\end{array}$ \\
& $\begin{array}{l}\text { SMART framework: Reduce sediment loads at } \\
\text { downstream water intake points by 15 percent within }\end{array}$ \\
& ten years.
\end{tabular}

\begin{tabular}{ll}
\hline Institutional & The Brazilian water PES \\
arrangement & institutions working on monitoring \\
& do not have good data \\
& organization. Four of five (80 \\
& percent) case studies do not present \\
& an integration of the monitored \\
& data and do not have a common \\
& means of making data available for \\
& society.
\end{tabular}

\begin{tabular}{ll}
\hline Methods & $\begin{array}{l}\text { All } 5 \text { (100 percent) of the case } \\
\text { studies have different methods to } \\
\text { monitor the results of the project. } \\
\text { This makes it difficult or even } \\
\text { impossible to compare the results. }\end{array}$ \\
\hline $\begin{array}{l}\text { Indicators (and } \\
\text { baseline) }\end{array}$ & $\begin{array}{l}\text {-Three of five (60 percent) case } \\
\text { studies have not done baseline } \\
\text { monitoring. }\end{array}$
\end{tabular}

-Significant variation between project indicators and monitoring frequency, indicating a lack of standardization.

-The indicators focus on hydrological aspects (mainly related to ecosystem functions) and interventions and rarely include benefits indicators.

- Hydrological-indicator monitoring is done at specific points of the watercourses, which hinders the integrated view of the basin. This practice can lead to distorted results, since the action at Create a common platform for organizing and making data available to decision-makers related to water PES monitoring and society.

The PES water programs should recommend or establish the same methods in their projects. Methods should be simplified, easy-to-apply, and low-cost when possible.

-The first year of monitoring can be considered as a baseline, but this monitoring must be done as soon as possible so as not to distort the results.

-Establish a standardization at least in the same program, using standard guides, recommended indicators, and frequencies aligned. This process will enable a comparison between the projects and results.

-It is also essential to have a set of indicators for each category (structure, functions, and benefits), to have complete monitoring.

- An integrated watershed monitoring can provide evidence where the sources of pollution that affect water quality are located. one point in the basin can affect all the drainage area (Odum, 2012).

Source: Interviews, Higgins and Zimmerling (2013), Fidalgo et al. (2017), UNEP-WCMC and FEBA (2020) and experience of authors. 


\section{CONCLUSIONS}

The literature review of Brazilian water PES monitoring showed that Brazilian water PES is still poorly monitored for several reasons, such as high cost, lack of specialized human resources, monitoring of functions, and methods of monitoring the impacts of projects on human well-being. The selection of the case studies exemplifies how it has been happening, showing the gaps and perspectives noted by the interviewees.

Water PES monitoring in Brazil has some serious gaps, especially regarding benefits. However, despite the predominance of ecological and hydrological indicators (ecosystem functions), the monitoring of the benefits has been gaining ground. Socioeconomic aspects demand attention since it is necessary to identify what impacts the PES have on the populations involved and to support decisions. In terms of indicators and methods used in water PES monitoring, it is concluded that there is no standardization and the monitoring varies widely from one project to another, depending on the resources available and the institutional arrangements made. It is recommended that low-cost and simple-to-apply indicators and methods be selected, with the involvement of the community, thus allowing their continuity and cost reduction. Another essential point is the dissemination of the results that need to be transparent and easier for the entire community. The project's objectives are very general. The PES objectives guide the monitoring, so it must be more precise and more established from a timeline perspective. It could help to identify the PES impacts on time.

The PES water represents a significant potential in the Brazilian context of forest restoration on private properties. With PES, the landowners can receive money and technical support to adjust their properties in legal terms. The PES water also can be a tool to stimulate community-wide environmental education. However, despite the potential, establishing a consistent monitoring system is essential to ensure that the projects will make the necessary adaptations and to identify the impacts on people's lives.

\section{ACKNOWLEDGEMENTS}

This study was financed by the Coordenação de Aperfeiçoamento de Pessoal de Nível Superior (CAPES) - Finance Code 00 and by National Council for Scientific and Technological Development - CNPq (308536/2018-5) is also gratefully acknowledged. We would like to thank Embrapa Solos, PUC Rio and International Institute for Sustainability (IIS-Rio) for the infrastructure that enabled the meetings, exchanges of information and the progress of the research. In particular, we thank the respondents who made great contributions to the research, updating data and giving information that was not available in the literature. In particular we are grateful to: Eileen Acosta, Hendrik Mansur, Vanessa Girão, André Targa Cavassani and Claudio Klemz (The Nature Conservancy), José Bento da Rocha (Agência Reguladora de águas, energia e saneamento básico do Distrito Federal), Henrique Marinho Leite Chaves (Universidade de Brasília-UNB), Everton Blainski (Empresa de pesquisa agropecuária e extensão rural de Santa Catarina), Paulo Henrique Pereira (Prefeitura de Extrema-MG), Renato Atanásio, Juliane Freitas and Carlos Augusto Wroblewski (Fundação Grupo Boticário de Proteção á Natureza), Rafaela Comparim Santos (Emasa-SC). We also would like to thank Azeneth Eufrasino Schuler and Elaine Cardoso Fidalgo, who contributed to this research in the initial step. This work was also supported by the National Council for Scientific and Technological Development (CNPq) from 2014 to 2016.

\section{REFERENCES}

ANA (Brasil). Programa produtor de água: manual operativo. Brasília, 2009. 67p. 
ANA (Brasil). Manual operativo do programa produtor de água. Brasília, 2012.84p.

ANA (Brasil). Conjuntura dos recursos hídricos no Brasil. Brasília, 2013. 432p.

ANA (Brasil). Conjuntura dos recursos hídricos: informe 2015. Brasília, 2015. 88p.

ANA (Brasil). Conjuntura dos recursos hídricos no Brasil 2018. Brasília, 2018. 72p.

BLUNDO-CANTO, G.; BAX, V.; QUINTERO, M.; CRUZ-GARCIA, G. S.; GROENEVELD, R. A.; PEREZ-MARULANDA, L. The different dimensions of livelihood impacts of Payments for Environmental Services (PES) schemes: a systematic review. Ecological Economics, v. 149, p. 160- 183, 2018. https://doi.org/10.1016/j.ecolecon.2018.03.011

BRASIL. Ministério do Meio Ambiente. Relatório Técnico de monitoramento do desmatamento no bioma cerrado, 2002 a 2008: dados revisados. 2012. Available at: http://siscom.ibama.gov.br/monitorabiomas/cerrado/Relatorio\%20tecnico_Monitoramen to\%20Desmate_Bioma\%20Cerrado_CSR_REV.pdf. Access: Jan. 2020.

BRAUMAN, K. A.; DAILY, G. C.; DUARTE, T. K.; MOONEY, H. A. Nature and value of ecosystem services: an overview highlighting hydrologic services. Annual Review of Environment and Resources, v. 32, p. 67-98, 2007.

BREMER, L. L.; AUERBACH, D. A.; GOLDSTEIN, J. H.; VOGL, A. L.; SHEMIE, D.; KROEGER, T. et al. One size does not fit all: Natural infrastructure investments within the Latin American Water Funds Partnership. Ecosystem Services, v. 17, p.217-236, 2016. https://doi.org/10.1016/j.ecoser.2015.12.006

BROUWER, R.; TESFAYE, A.; PAUW, A. P. Meta-analysis of institutional-economic factors explaining the environmental performance of payments for watershed services. Environmental Conservation, v. 38, n. 4, p. 380-392, 2011. https://dx.doi.org/10.1017/S0376892911000543

CAMHI, A.; PAGIOLA, S. Payment for Environmental Services mechanisms in Latin America and the Caribbean: a compendium. Washington: World Bank., 2009.

ELLIS, E. C.; RAMANKUTTY, N. Putting people in the map: anthropogenic biomes of the world. Frontiers in Ecology and the Environment, v. 6, n. 8, p. 439-447, 2008. https://dx.doi.org/10.1890/070062

FAO. State of the World's Forests 2016: Forests and agriculture: land-use challenges and opportunities. Geneva, 2016. Available at: http://www.fao.org/3/a-i5588e.pdf. Access: Sep. 2020.

FIDALGO, E. C. C.; PRADO, R. B.; TURETTA, A. P. D.; SCHULER, A. E. Manual para pagamento por serviços ambientais hídricos: seleção de áreas e monitoramento. Brasília: Embrapa, 2017, 80 p.

FILOSO, S.; BEZZERA, M. O.; WEISS, K. C. B.; PALMER, M. A. Impacts of forest restoration on water yield: a systematic review. Plos One, v. 12, n. 8, 2017. https://dx.doi.org/10.1371/journal.pone.0183210

FORMPLUS. Structured interviews: definition, types + question examples. 2020. Available at: https://www.formpl.us/blog/structured-interview. Access: Jun.2020. 
GIBBS, H. K.; RUESCH, A. S.; ACHARD, F.; CLAYTON, M. K.; HOLMGREN, P.; RAMANKUTY, N. et al. Tropical Forests were the primary sources of new agricultural land in the 1980s and 1990s. PNAS, v. 107, n. 38, p. 16732-7, 2010. https://dx.doi.org/10.1073/pnas.0910275107

GOETZ, R. U. Editorial Water Management and the Payments of Environmental Services. $\begin{array}{lllllll}\text { Water Economics and Policy, v. 5, n. } & \text { 4, } 2019 .\end{array}$ https://dx.doi.org/10.1142/S2382624X19030012

GREINER, R.; STANLEY, O. More than money for conservation: exploring social co-benefits from PES schemes. Land Use Policy, v. 31, p. 4-10, 2013. https://doi.org/10.1016/j.landusepol.2011.11.012

HAINES-YOUNG, R.; POTSCHIN, M. The links between biodiversity, ecosystem services and human well-being. In: RAFFAELLI, D. G.; CHRISTOPHER L. J. Ecosystem Ecology: a New Synthesis. Cambridge: University Press, 2010. 174 p. Available at: https://www.nottingham.ac.uk/cem/pdf/Haines-Young\&Potschin_2010.pdf. Access: Oct. 2019.

HIGgins, J. V.; ZIMMerling, A. (eds.) A Primer for Monitoring Water Funds. Arlington, VA: The Nature Conservancy, 2013. Available at: https://www.nature.org/media/freshwater/Water_Funds_Primer_on_Monitoring_2013.p df. Access: Jul. 2020.

IBGE. Cerrado: berço das águas. 2018. Available at: https://agenciadenoticias.ibge.gov.br/media/com_mediaibge/arquivos/19fedbc1a720967 94982c9b28dfa97d8.pdf. Access: Jan. 2020.

JENKINS, M.; SCHAAP, B. Forest Ecosystem Services. 2018. 41p. Available at: https://www.un.org/esa/forests/wp-

content/uploads/2018/05/UNFF13_BkgdStudy_ForestsEcoServices.pdf. Access: Jun. 2019.

LATAWIEC, A. E.; AGOL, D. Conclusions- Sustainability Indicators in Practice: Lessons Learned From the Past, Directions for the future. In: LATAWIEC, A. E.; AGOL, D. Sustainability Indicators in Practice. Berlim: De Gruyer Open, 2015. p. 244-246. Available at: https://www.degruyter.com/viewbooktoc/product/465479. Access: Mar.2020.

LATAWIEC, A. E. Creating space for large-scale restoration in tropical agricultural landscapes. Frontiers in Ecology and the Environment, v. 13, p. 211-218, 2015. https://dx.doi.org/10.1890/140052

LAURANCE, W. F. Conserving the hottests of the hotspots. Biological Conservation, v. 142, p. 1137, 2009. https://dx.doi.org/10.1016/j.biocon.2008.10.011

LIMA, A. P. M. Estado da Arte do Monitoramento de Pagamentos por Serviços Ambientais Hídricos no Brasil. 2016. 60f. Monografia (Bacharelado em Geografia) PUC, Rio de Janeiro, 2016.

LOCATELLI, B.; IMBACH, P.; WUNDER, S. Synergies and trade-offs between ecosystem services in Costa Rica. Environmental Conservation, v. 41, n. 1, p. 27-36, 2013. https://dx.doi.org/10.1017/S0376892913000234 
MAGNAGO, L. F. S.; MAGRACH, A.; LAURANCE, W.F.; MARTINS, S.V.; MEIRA NETO, J. A. A.; SIMONELLI, M. et al. Would protecting tropical forest fragments provide carbon and biodiversity co benefits under REDD+? Global Change Biology, v. 21, p. 3455-3468, 2015. https://dx.doi.org/10.1111/gcb.12937

MARTIN-ORTEGA, J.; OJEA, E.; ROUX, C. Payments for Water Ecosystem Services in Latin America: a literature review and conceptual model. Ecosystem Services, v. 6, p. 122 132, 2013. https://doi.org/10.1016/j.ecoser.2013.09.008

MARTINS, C. R.; LOPES, W. A.; ANDRADE, J. B. Solubilidade das substâncias orgânicas. Química Nova, v. 36, n. 8, p. 1248-1255, 2013. https://doi.org/10.1590/S010040422013000800026

MEIJERINK, G. The role of measurement problems and Monitoring in PES Schemes. In: DELLINK, R. B.; RUIJS, A. (eds.). Economics of Poverty, Environment and Natural Resource Use. Dordrecht: Springer, 2008. p. 61-85. Available at: https://edepot.wur.nl/954. Access: Jan. 2020.

NOVAES, R. M. L. Monitoramento em Programas e Políticas de Pagamentos por Serviços Ambientais em Atividade no Brasil. Estudos Sociedade e Agricultura, v. 22, n. 2, p.408431, 2014.

NUSDEO, A. M. O. Pagamento por serviços ambientais: do debate de política ambiental à implementação jurídica. In: LAVRATTI, P.; TEJEIRO, G. Direito e mudanças climáticas: pagamentos por serviços ambientais, fundamentos e principais aspectos jurídicos. São Paulo: Instituto O Direito por um Planta Verde, 2013. v. 6. p.8-45.

ODUM, E. P. Ecologia. Rio de Janeiro: Guanabara Koogan, 2012.

PAGIOLA, S.; VON GLEHN, H. C.; TAFFARELLO, D. Experiências de pagamentos por serviços ambientais no Brasil. São Paulo: Secretaria do Meio Ambiente, 2012. 336 p.

PEREIRA, L. C.; TÔSTO, S. G.; ROMEIRO, A. R. Uso das terras: perdas de solo por erosão e valoração econômica. In: SEABRA, G. Terra: mudanças climáticas e biodiversidade. Ituiutaba: Barlavento, 2019. p. 929-943. Available at: https://www.alice.cnptia.embrapa.br/handle/doc/1110638. Access: Feb. 2020.

PRADO, R.B., FORMIGA-JOHNSSON, R. M., MARQUES, G. Uso e Gestão da Água Desafios para a sustentabilidade no meio rural. 2017. Boletim Informativo da SBCS. Available at: https://www.sbcs.org.br/wpcontent/uploads/2017/09/boletimsbcswebsetdez.pdf. Access: Jun. 2019.

RICHARDS, M.; JENKINS, M. Potential and Challenges of Payments for Ecosystem Services from Tropical Forests. (S.1.): FPEP, 2007. (Forestry Briefing, 16).

SOS MATA ATLÂNTICA. Website. 2020. Available at: https://www.sosma.org.br/. Access: June 2020.

SOARES-FILHO, B. et al. Cracking Brazil's Forest Code. Science, v. 344, n. 6182, p. 363-364, 2014. https://dx.doi.org/10.1126/science.1246663

STRASSBURG, B. N.; RODRIGUES, ANA S. L.; MYKOLA, G.; ANDREW, B.; FRITZ, S.; Obersteiner, M. et al. Impacts of incentives to reduce emissions from deforestation on global species extinctions. Nature Climate Change, v. 2, p. 350-355, 2012. https://doi.org/10.1038/nclimate1375 
STRASSBURG, B. et al. When enough should be enough: Improving the use of current agricultural lands could meet production demands and spare natural habitats in Brazil. $\begin{array}{lllllll}\text { Global Environmental Change, } & \text { v. 28, p. 84-97, } 2014 .\end{array}$ https://doi.org/10.1016/j.gloenvcha.2014.06.001

TERRADO, M.; LAVIGNE, M. P.; TREMBLAY, S.; DUCHESNE, S.; VILLENEUVE, J. P.; ROUSSEAU, A. N. Distribution and assessment of surface water contamination by application of chemometric and deterministic models. Journal of Hydrology, v. 369, p. 416-426, 2009. https://doi.org/10.1016/j.jhydrol.2009.02.030

TURETTA, A. P. D.; PRADO, R. B.; COUTINHO, H. L.; FIDALGO, E. C. C.; SCHULER, A. E.; MARTINS, A. L. S. et al. Memória da oficina ranqueamento de indicadores de serviços ambientais. Brasília: Embrapa Solos, 2013. Available at: https://www.embrapa.br/busca-de-publicacoes/-/publicacao/980385/memoria-daoficina-ranqueamento-de-indicadores-de-servicos-ambientais. Access: Feb.2020.

UNEP-WCMC; FEBA Guidebook for Monitoring and Evaluating Ecosystem-based Adaptation Intervention. Bonn: GIZ, 2020. 84p. Available at: https://www.adaptationcommunity.net/download/ME-Guidebook_EbA.pdf. Access: Jan.2020.

UNESCO. Global water resources under increasing pressure from rapidly growing demands and climate change, according to new UN World Water Development Report. 2015a. Available at: http://www.unesco.org/new/fileadmin/MULTIMEDIA/HQ/SC/pdf/WWDR4\%20Backg round\%20Briefing\%20Note_ENG.pdf. Access: Dec. 2019.

UNESCO. Water for a sustainable world: facts and figures. 2015b. Available at: http://www.unesco.org/new/fileadmin/MULTIMEDIA/HQ/SC/images/WWDR2015Fac ts_Figures_ENG_web.pdf. Access: Feb. 2020.

VEIGA, F.; GALVADÃO, M. Iniciativas de PSA de Conservação dos Recursos Hídricos na Mata Atlântica. In: GUEDES, F. B.; SEEHUSEN, S. E. (eds.). Pagamentos por serviços ambientais na Mata Atlântica: lições aprendidas e desafios. Brasília: MMA, 2011. p. 123-146.

WWF. Importance of forests. 2018. Available at: http://wwf.panda.org/about_our_earth/deforestation/importance_forests/. Access: Sep. 2020. 